\title{
EARLY CHRISTIANITY IN THE REGION OF SOPIANAE AND THE NEW CASKET MOUNTS FROM BAKONYA
}

Summary: Christianity spread out in Pannonia, too, and in the 3rd century there are proofs of its existence in the southern part of both Pannonias. Christianity became stronger in consequence of placing the officium praesidis of Valeria to Sopianae at the end of the 3rd century. The flourishing of ancient Christianity in Sopianae and in the surrounding villas was in the second half of the 4th century. The bronze casket mounts recently found in Bakonya support this historical reconstruction and offer new evidence for the presence of rich Christians in that era.

Key words: Christianity, late Roman villas, casket mounts, biblical scenes, four seasons representation

At the end of the 3rd century Diocletianus launched many significant reforms. One of them was the reform of state administration. By that time Rome had approximately fifty provinces, which were divided up and reorganized in more than one hundred units. The two Pannonias were also divided and after that they included four new provinces. The northern part of Pannonia inferior was named after the daughter of Diocletianus, Valeria, while the southern part became the more ordinary Pannonia secunda. Supposedly due to the extension of the territorium of Mursa, the border of the neighbouring provinces was not established along the River Drave but somewhat north of it. ${ }^{1}$ The other important achievement of the administrative reform was the sharing of power between military and civilian governance. Since Valeria was situated at the border of the Empire, a large military force stationed in the province. The military command resided in Aquincum, but instead of a legatus, a dux was in charge.

\footnotetext{
* Manuscript received: January 20, 2020, accepted: January 20, 2020.

${ }^{1}$ Tóth, E.: A pogány és keresztény Sopianae [Pagan and Christian Sopianae]. Specimina Nova XX (2006) 49-102, here 60.
} 
The head of the civilian government was the praeses, who held his office presumably in Sopianae. ${ }^{2}$ The indirect proof of his residence was provided by Ammianus Marcellinus: Maximinus regens quondam Romae vicariam praefecturam apud Sopianas Valeriae oppidum obscurissime natus est patre tabulario praesidialis officii orto a posteritate Carporum, quos antiquis excitos sedibus Diocletianus transtulit in Pannoniam. ${ }^{3}$ Maximinus started his career around 360. In 370-371, he was the vicarius of Rome, then the praefectus praetorio of Gaul. He was beheaded by Gratianus around $376 .{ }^{4}$ The Carps were settled in Pannonia inferior by Galerius, after he had defeated them in $295^{5}$

Although there are no direct and unambiguous proofs regarding the centre of the province, according to most researchers the significant late Roman development of Sopianae, its flourishing economy, the well-being of its populace and leaders obviously indicate the leading role of the settlement. ${ }^{6}$ Earlier this was only shown by the findings of the late Roman cemetery but later on the excavations carried out during the last decades have also supported this theory. According to Fülep the monumental building, found in the forum one hundred years ago, was the palace of the praeses, ${ }^{7}$ while, according to its excavator, the recently uncovered basilica built in the last third of the 4th century and situated to the south was an early Christian basilica. ${ }^{8}$ It is very likely that the town wall of Sopianae was also built in the second half or the last third of the 4 th century. ${ }^{9}$

Christianity had been spreading in the Danube provinces since the 2nd century. The main missionaries of the religion were Greeks or Orientals. In Pannonia the earliest representatives were the bishops Eusebius in Cibalae and Victorinus in Poetovio, in the late 3rd century. However, in the southern towns of the province, above all in Sirmium, Bassiana, Mursa and Siscia, there could have been more Christian communities, which is indicated by the many Christian martyrs in Pannonia secunda at the beginning of the 4th century. Following the persecution, Christianity spread very

\footnotetext{
${ }^{2}$ FÜLEP, F.: Sopianae [Archaeologia Hungarica 50]. Budapest 1984, 274; NAGY, T.: Sopianae. Egy új városmonográfia margójára [Sopianae. Remarks to a new town monograph]. Antik Tanulmányok 33 (1987-1988) 218-245, here 240; KÁRPÁTI, G.: The Roman Settlement of Sopianae. Situla 42 (2004) 279-287, here 281; ТóTH (n. 1) 60.

${ }^{3}$ Amm. XXVIII 1. 5 - Maximinus, who had earlier led the vicaria praefectura of Rome, was born in Sopianae, Valeria. His father was a clerk working in the praeses' office, and descendant of the Carps settled from their old home in Pannonia by Diocletianus.

${ }_{4}^{4}$ FITZ, J.: Die Verwaltung Pannoniens in der Römerzeit I-IV. Budapest 1993-1995, here 13091310.

${ }^{5}$ MóCSY, A.: Pannonia. In PWRE Suppl. IX. Stuttgart 1962, 515-776, here 571.

${ }^{6}$ See recently VISY, Zs.: Sopianae története [History of Sopianae]. In VISY, Zs. (ed.): Pécs története I. Az öskortól a püspökség megalapitásáig. Pécs 2013, 93-152, 271-275; English summary 345348; here 135-136.

${ }_{8}^{7}$ FÜLEP (n. 2) 274.

${ }^{8}$ TóTH, ZS.: A Rákóczi út - Jókai utca saroktelken végzett 2008-2009. évi régészeti feltárásról [On the excavation on the corner plot of Rákóczi Street/Jókai Street in 2008-2009]. Pécsi Szemle 13.2 (2010) 8-27, here 23-25.

${ }^{9}$ KÁRPÁTI (n. 2) 284; VISY (n. 6) 143.
} 
quickly in Pannonia. ${ }^{10}$ Bigger settlements, like Sirmium, Poetovio, Siscia and Cibalae, and supposedly also Sopianae, had their own bishops.

After the Nicene Council held in 325, Arius was exiled to Sirmium, and this region became the nest of heresy. North of the River Drave, Sopianae and its surroundings were the significant centres of Christianity. ${ }^{11}$ The increasing importance of this religion is well represented by the burial chapels and vaults, the Christian cemetery of the civilian centre of Valeria ${ }^{12}$ and the recently excavated mausoleum in Alsóhetény. ${ }^{13}$ But Christian communities lived in other towns as well, above others in Savaria and Aquincum, and the religion spread widely not only along the frontiers but also in the inner areas. ${ }^{14}$

Since written sources, including inscriptions, relating to the Christian population living in Pannonia are quite poor and incomplete, material finds characterize early Christians more effectively. The early Christian cemetery of Pécs is abundant in different types of funeral buildings, but the reconstructed burial crypt of Kővágószőlős is also in good condition. ${ }^{15}$ At the beginning, the orientation of Christian churches and chapels was not homogenous but from the middle of the 4th century, the Eastern orientation became more generally used. The crypts were built for wealthy dignitaries or martyrs, like the chapel of Synerotas in Sirmium. ${ }^{16}$

As the civilian centre of the province, Sopianae was a significant religious centre as well. It is quite certain that the Christian community of the town was led by a bishop. The proximity and the presumable influence of Mursa relates to the effects of Arius' teaching, which denied Jesus' homoousios nature and emphasized his created nature. Around 330 Valens, one of his followers, became the bishop of Mursa. ${ }^{17}$ In the sixties of the 4 th century the orthodox faction could marginalize the followers

${ }^{10}$ NAGY, L.: Pannonia sacra. In Szent István emlékkönyv I. Budapest 1938, 31-148; NAGY, T.: A pannoniai kereszténység története a római védőrendszer összeomlásáig [Dissertationes Pannonicae II.12]. Budapest 1939; TóTH, E.: Das Christentum in Pannonien bis zum 7. Jahrhundert nach den archäologischen Zeugnissen. In BoshOF, E. - WolfF, H. (Hrsg.): Das Christentum im bairischen Raum. KölnWeimar-Wien 1994, 241-272, here 243.

${ }^{11}$ FÜleP (n. 2) 279-280; FÜleP, F. - BACHMAN, Z. - PINTÉR, A.: Sopianae-Pécs ókeresztény emlékei [The early Christian monuments of Sopianae-Pécs]. Budapest 1988.

12 KATONA GYÖR, Zs.: Temetkezési szokások a római kori Sopianaeban. In VISY (n. 6) 153-194, 275-281, English summary 349-351; GÁBOR, O.: Sopianae ókeresztény temetőjének épületei. In VISY (n. 6) 195-222, 281-285, English summary 351.

${ }^{13}$ TÓTH, E.: Az alsóhetényi 4. századi erőd és temető kutatása, 1981-1986. Eredmények és vitás kérdések [Research on the $4^{\text {th }}$-century fortification and cemetery in Alsóhetény, 1981-1986. Results and debated issues]. Archeologiai Értesitö 114 (1987-1988) 22-61, here 22-41.

${ }^{14}$ То́тн: Das Christentum (n. 10) 243.

${ }^{15}$ Sz. Burger, A.: The Roman Villa and Mausoleum at Kővágószőlős. Janus Pannonius Múzeum Évkönyve 30-31 (1985-1986) 65-228, here 165-179; HAJNÓCZI, GY. J.: The Conceptual and Actual Reconstruction of the Villa and the Burial Vault at Kővágószőlős. Janus Pannonius Múzeum Évkönyve 30-31 (1985-1986) 229-236.

${ }^{16}$ NAGY: A pannoniai kereszténység (n. 10) 68-69; MiLOŠEVIĆ, P.: Earlier Archaeological Activity in Sirmium. In Popović, V. - OChSENSCHLAGER, E. L. (eds): Sirmium. Archaeological Investigations in Sirmian Pannonia II. Beograd 1974, 3-11.

${ }^{17}$ NAGY: A pannoniai kereszténység (n. 10) 87-94. 
of Arius only in consequence of sharp theological disputes. Later on the energetic deeds of Ambrosius forced back the teachings and followers of Arius. ${ }^{18}$

Sometimes it is quite hard to decide whether a building or some part of it was used as a Christian church or for some profane purposes. But there are some fortunate cases as well. The owner of the late Roman villa of Kővágószőlős, which is in the vicinity of Sopianae, was obviously a wealthy dignitary, because he was buried in a painted crypt built under the tomb-chapel standing just in front of the villa. The preliminary description of the paintings in the $\mathrm{Crypt}^{19}$ refers to his Christian belief.

Christian symbols can often be seen on the finds, but a connection between these depictions and the Christians is usually only a possibility. ${ }^{20}$ It cannot be stated whether the users of these items were real or just pseudo-Christians. ${ }^{21}$ The reticulated bronze Christogram, found during the last restoration of crypt I, decorated the chain of a bronze lucerna. ${ }^{22}$ Since the early Christian symbol was found in the early Christian cemetery, it was obviously used for cultic ceremonies held in the graveyard. Similar conclusions can be considered in connection with the little hanging Christogram, made from a silver coin, and the stamped bronze ring, decorated by the initials of Christ. Both items were found in Pécs. ${ }^{23}$ A similar bronze ring was found in Magyaregregy, and a bronze plate, stamped with the aforementioned symbol in its middle, in Szilágy-Aranyoldal. ${ }^{24}$ The gold-foiled glass disc (fondo d'oro) with an inscription around the Christian depiction from Dunaszekcső is a rare early Christian find. ${ }^{25}$

Many villas built in the vicinity of Sopianae have not been excavated yet and can only be estimated based on the surface findings and observations. They show that a group of bigger and richer villas can be distinguished. These villas built and sometimes rebuilt in the 4 th century along the limes or a little bit further from Sopianae exceeded contemporary farm houses in their measures and wealth. ${ }^{26}$ These Late Roman differences highlight the intensive urban development of Sopianae, which is enhanced by the establishment of the centre of the civil administration of the province.

${ }^{18}$ NAGY: A pannoniai kereszténység (n. 10) 157-170.

${ }^{19}$ BURGER (n. 15) 176-179.

${ }^{20}$ ThOMAS, CH.: Christianity in Roman Britain to AD 500. London 1981, 256.

${ }^{21}$ UBL, H.: Die Christianisierung von Noricum Ripense bis zum 7. Jahrhundert nach den archäologischen Zeugnissen. In BOSHOF-WOLFF (n. 10) 150; GÁSPÁR, D.: Pannonia kereszténysége a mai Magyarország területén [The Christianity of Pannonia in the territory of present-day Hungary]. Budapest 2008, passim.

${ }^{22}$ KATONA GYÖR, ZS.: Az első keresztények a Dél-Dunántúlon az ókeresztény temetők tükrében. Sopianae [The first Christians in Southern Transdanubia as evidenced by early Christian cemeteries. Sopianae]. In Kereszténység és államiság Baranyában - Pécsvárad 2000-2001. Kiállítási katalógus. Pécs 2000, Kat. 34; POZSÁRKÓ, CS.: A világörökségi krisztogram kapcsán [Apropos the World Heritage Christogram]. Pécsi Szemle 5 (2002) 2-4.

${ }_{23}^{23}$ KATONA GYÖR: Az elsö keresztények (n. 22) Kat. 40, 46.

${ }^{24}$ KATONA GYÖR: Az első keresztények (n. 22) 12, 35. - The ring of Magyaregregy was found in Kisvaszar by FÜLEP (n. 2) 279.

${ }^{25}$ NAGY: Pannonia sacra (n. 10) 42-45; most recently FÜLEP (n. 2) 279.

${ }^{26}$ VISY (n. 6) $148-150$. 
In the case of both the excavated and observed villas, the findings verified their use in the 4th century and in some apparent cases even in the 5 th century. ${ }^{27}$ The excavated villas of Kővágószőlős, Hosszúhetény and Komló-Mecsekjánosi ${ }^{28}$ belong to the groups of peristyle buildings, such as the ones in Bakonya and Cserdi. ${ }^{29}$ The latter ones were surveyed with aerial photos. ${ }^{30}$ The villa built in Nagyharsány also belongs to this group. ${ }^{31}$ The villas built in Kővágószőlős, Cserdi and Bakonya had their own baths and all the farm buildings can be recognized on the aerial photos. More villas had mosaics but unfortunately they are not in a recognizable condition. The walls were generally painted. These illustrious villas built in the territory of Pécs or at the southern foot of the Mecsek and Villány mountains were surrounded by large estates whose real size cannot be estimated. Besides the bigger villas and farms there were smaller ones as well. The excavated buildings in Komló-Mecsekújfalu Street, Nagyárpád and Babarc are of this kind. ${ }^{32}$ The owners of the poorer farms could have been middle class citizens or veterans.

$$
* * *
$$

During the control of a find announcement two folded broken bronze plates were found $^{33}$ in the territory of the Roman villa at Bakonya. They could be identified as casket mounts decorated with scenes (figs 1-2). The find spot is the territory of one

${ }^{27}$ VISY, ZS.: Die ländliche Besiedlung und Landwirtschaft in Niederpannonien. In BENDER, H. WolfF, H. (Hrsg.): Die ländliche Besiedlung und Landwirtschaft in den Rhein-Donau-Provinzen des Römischen Reiches [Passauer Universitätsschriften zur Archäologie 2]. Espelkamp 1994, 421-449, here 447-449; GÁBOR, O.: Suburbanum Sopianarum. Az antik Pécs város környéke és vonzáskörzete [The surroundings and the catchment area of the ancient town of Pécs]. In SzIRTES, G. - VARGHA, D. (eds): Mozaikok Pécs és Baranya gazdaságtörténetéböl. Pécs 2005, 9-23, here 12-16.

${ }^{28}$ Kővágószőlős: Sz. BURGER (n. 15) 69, fig. 2b; Hosszúhetény: DOMBAY, J.: Későrómai temetők Baranyában [Late Roman cemeteries in Baranya County]. Janus Pannonius Múzeum Évkönyve 2 (Pécs, 1957) 181-330, here 182, B. ThOMAS, E.: Römische Villen in Pannonien. Budapest 1964, 274-278; FÜleP, F. - Sz. Burger, A.: Baranya megye a római korban [Baranya County in the Roman Age]. In BÁNDI, G. (ed.): Baranya megye története. Pécs 1979, 223-317, here 273; Komló Mecsekjánosi út: Sz. BURGER, A.: Római kori villa maradványai Komló határában [The ruins of the Roman villa in Komló]. Janus Pannonius Múzeum Évkönyve 1967 (Pécs 1968) 61-67; FÜLEP-BURGER 275-276; B. THOMAS (n. 28) 278-279.

${ }^{29}$ Bakonya: BertóK, G. - KovAliczKy, G.: Római villa Bakonya-Csucsai dülöben [A Roman villa in Bakonya-Csucsai dülő]. In BíRÓ, Sz. (ed.): Firkák I. Fiatal Római Koros Régészek I. konferenciakötete. Györ 2007, 345-350, here 345-349; Cserdi: VISY (n. 6) 149.

${ }^{30}$ Pécsi Légirégészeti Téka, photographed by M. Szabó; cf. SzABÓ, M.: Régészet madártávlatból. Fejezetek a Pécsi Légirégészeti Téka 20 éves történetéböl [Archaeology from above. Episodes from the History of the Aerial Archaeology Archive of Pécs]. Archaeolingua, Budapest 2016, figs 8-11, $223-224$.

${ }^{31}$ GÁBOR, O.: Villae Romanae around Sopianae (Pécs) in County Baranya. Situla 42 (2004) 276279, here 278, fig. 3.3; MRÁv, Zs.: Egy későrómai luxusvilla Nagyharsányban [A Late Roman luxury villa in Nagyharsány]. Várak, kastélyok, templomok XV2019, 18-21.

${ }^{32}$ Komló-Mecsekfalui út: KATONA GYÖR, Zs.: Római villaépület Komló, Mecsekjánosi úton [Roman villa in Komló, Mecsekjánosi Street]. JPMÉ 38 (1993) [1994] 67-94; Pécs-Nagyárpád: B. THOMAS (n. 28) 279, FÜlEP-BuRger (n. 28) 283-284; Babarc: BENDER, H. - BuRnS S, T. - VISY, ZS.: Zusammenfassung. In FAZEKAS, F. (ed.): Die römische Siedlung bei Babarc. [Passauer Universitätsschriften zur Archäologie 12]. Passau 2007, 193-200.

${ }^{33}$ Inspection of Zs. Visy, É. Szajcsán, M. Szabó and R. Lóki on the 15th April 2010. 


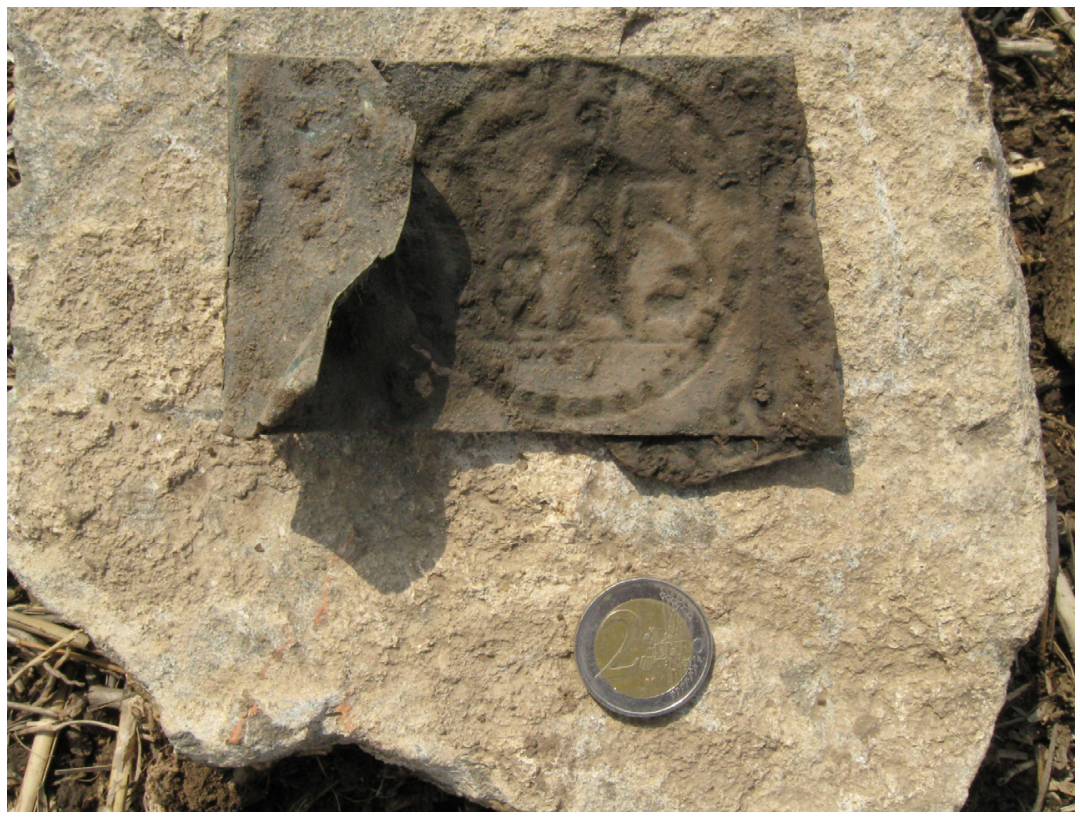

1. The three-folded bronze plate with biblical scenes at the time and in the place of finding. (C) Zs. Visy

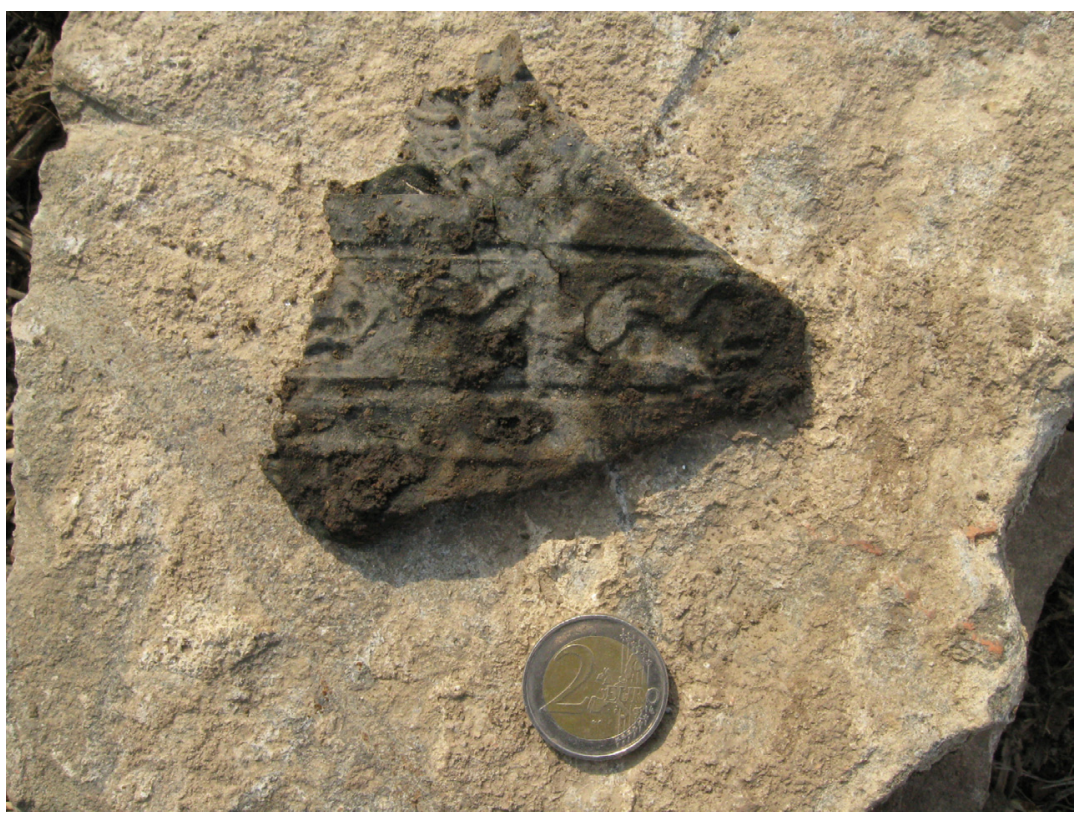

2. The bronze plate of a casket with the personification of Winter at the time and in the place of finding. (C) Zs. Visy 


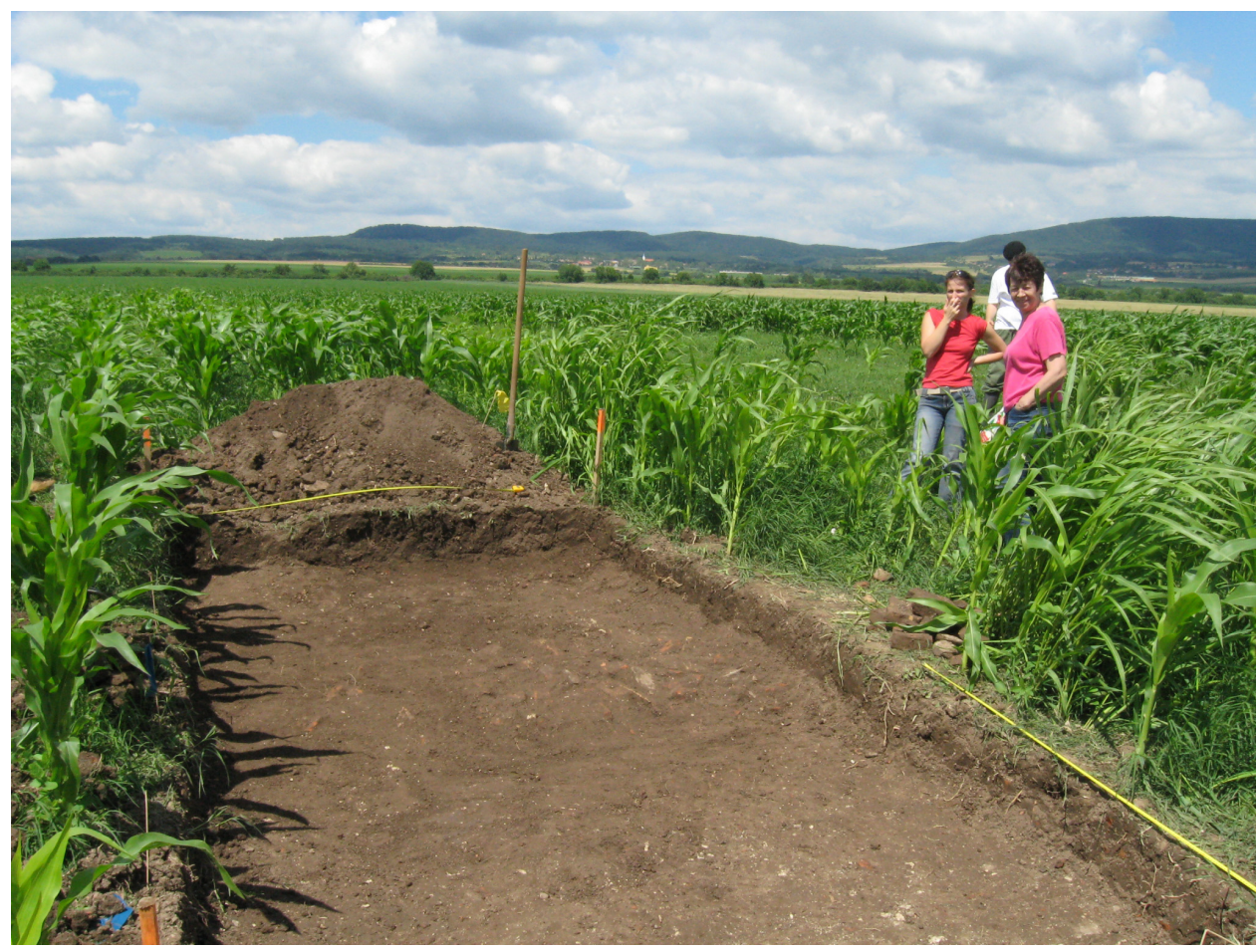

3. The control excavation in the find spot of the casket fittings, with Katalin V. Gémes in the forefront. (c) Zs. Visy

of the economic buildings of the villa, but the broken and folded condition of the plates may refer to their secondary place within the late Roman estate. This could be maintained also by the fact that during the control excavation ${ }^{34}$ no more details of the casket(s) were found in the same location (fig. 3). ${ }^{35}$ One of the casket mounts was decorated by an early Christian scene and the other with a personification of Winter. Based on this fortunate find it is plausible that the owner of the villa in Bakonya was a Christian.

The bronze plate with biblical scenes was folded in three. It was partly opened during the restoration so that its decoration can be observed. The folded part on the right side is without any decoration so it was left in its original form. Its full extension is 23.9 by $6.7 \mathrm{~cm}$, the plate is $0.3 \mathrm{~mm}$ thick (figs $4-5$ ). The left side is broken; there are more cracks in the lower side. The plate was fixed to the casket with nails, their holes can be observed in the border line of the motifs in the upper and lower edge of

\footnotetext{
${ }^{34}$ Excavation of Zs. Visy on 21st-25th June 2010 under the participation of M. Szabó, R. Lóki, I. Talabér and P. Czukor.

${ }^{35}$ The restoration of the decorated plates of the bronze casket was the last work of Katalin V. Gémes (1946-2011). I sincerely thank her for it.
} 


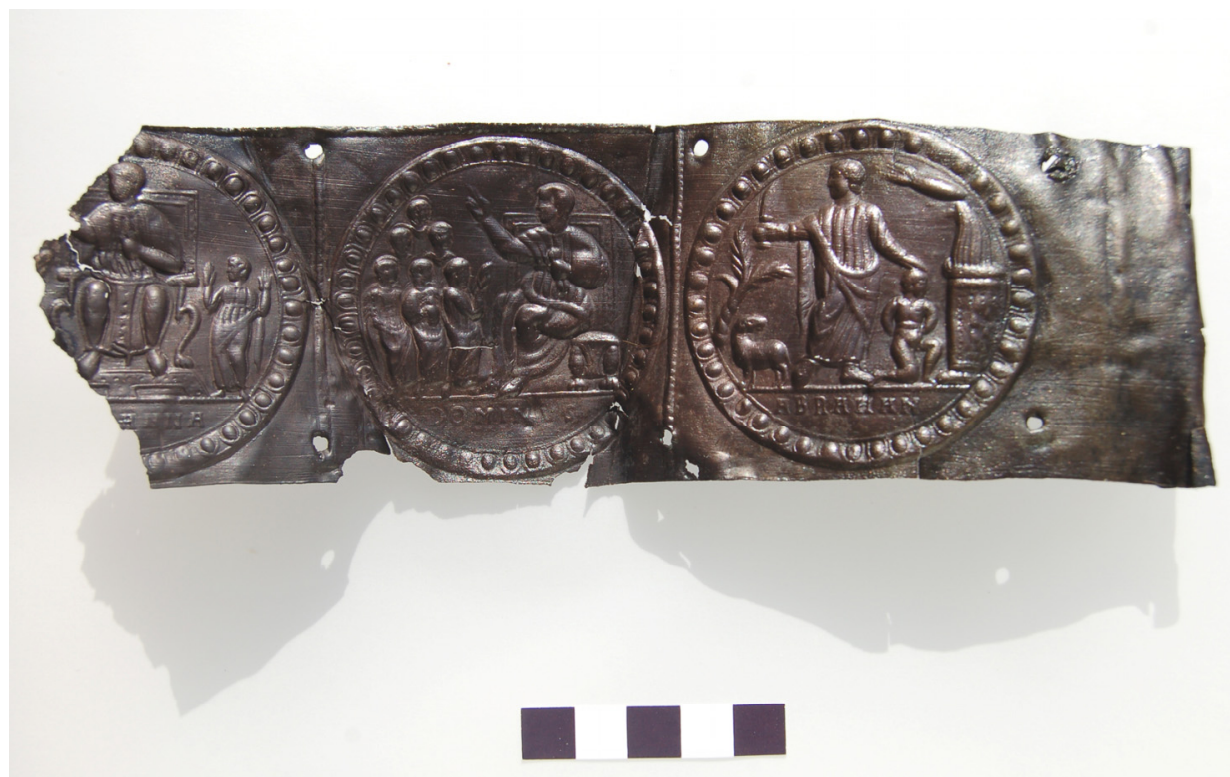

4. Obverse of the plate with biblical scenes. (C) Zs. Visy

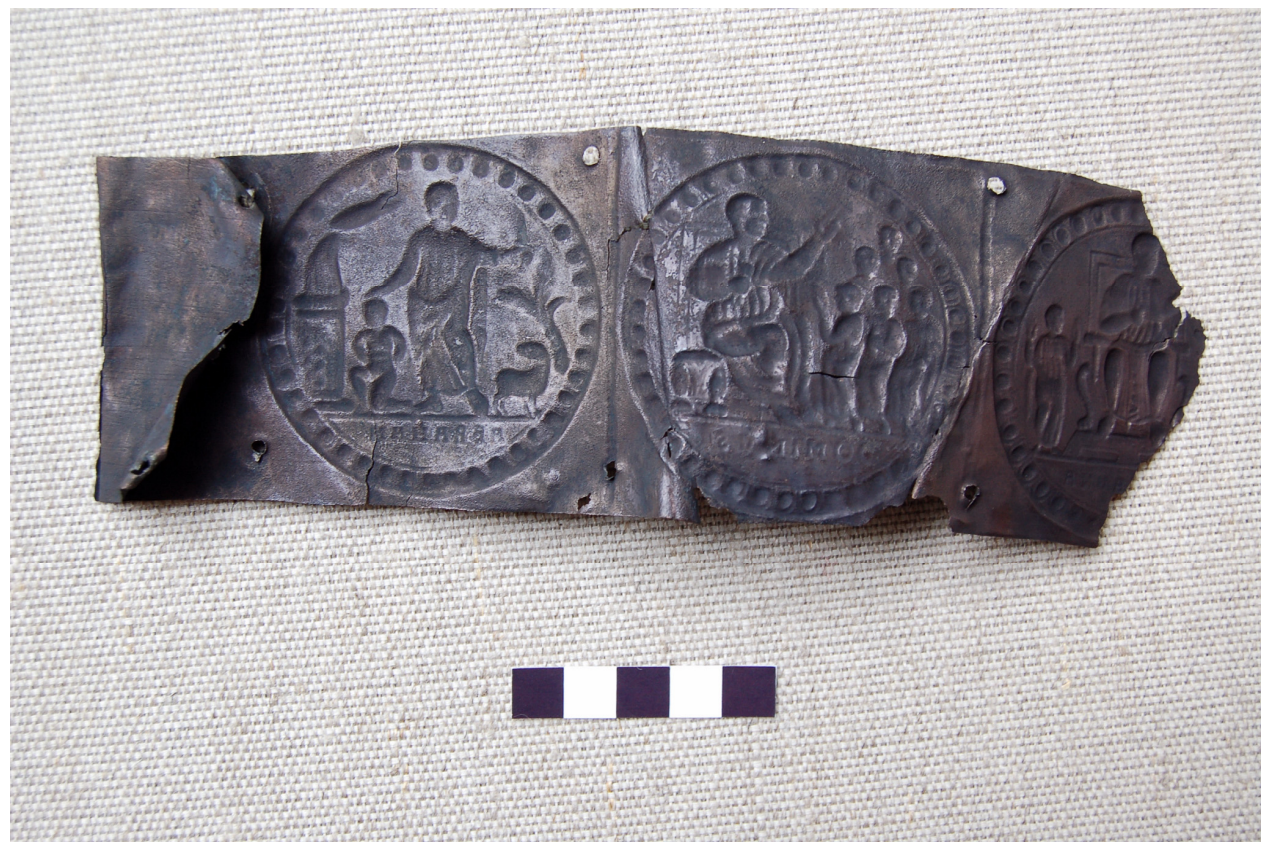

5. Reverse of the plate with biblical scenes. (C) Zs. Visy 
the plate. There are also holes on the folded, undecorated part, but here there is a hole also in the middle. The three scenes were arranged horizontally. They are intact except for the left scene where the outer part is missing. In the edge above two scenes a thin ribbed line can be observed, which is missing from above the right scene, surely because here the plate becomes narrower. The round scenes were divided by small pearled sticks, but on the outer side of the right scene there is no such decoration. The width of the folded part is $5.5 \mathrm{~cm}$. It is likely that this part was originally bent in right angle and nailed on the side of the casket.

All scenes are encircled by a pearl-ribbed ring in a diameter of $6.5 \mathrm{~cm}$. The ring itself is $0.6 \mathrm{~cm}$ wide. There is a thin rib in the inner side. The same diameter of the rings speaks for a common, identical press form. However, the big pearls in them were made separately, because their number is different in the two intact rings: 42 and 40. Round the pearls hemispherical curves can be observed. The almost hemispherical pearl decoration became generally used from the middle of 4 th century. ${ }^{36}$

The left scene depicts the large figure of Dominus, who is sitting on an arched legged throne, while the throne and his legs are on a stool (figs 6-7). A horizontal pearled rib represents the bottom of the scene. The ornamented throne and stool of pearled decoration are obviously the throne of the Emperor, which is also used on the triumphant Christ depictions. ${ }^{37}$ Dominus, who is looking to the right, holds his right arm (which is incomplete in the scene) in an elevated blessing position, while in his left hand he holds the scroll of laws. He wears a tunica and a cloak. His long and wide belt, which is dangling to his ankles, is decorated by round ornaments. Next to him a much smaller orans figure can be seen. Based on the symmetrical structure of this picture and other similar depictions the missing part could have been another orans figure as well. They are the apostles Peter and Paul. The scene is similar to the Emperor sitting on his throne, depicted from the front, showing Christ, the eternal Lord of the universe in the centre. ${ }^{38}$ The inscription at the bottom is incomplete, but its completion is surely [HOS]ANNA. ${ }^{39}$ It is the first time that this word can be read on such a depiction. Thus the inscription is in harmony with the picture. Its forerunners were similar scenes of Emperors. First it could be seen on the gold coins of Constantinus ${ }^{40}$

\footnotetext{
${ }^{36}$ It regularly appears on late Roman casket findings, GÁSPÁR, D.: Römische Kästchen aus Pannonien I-II. Antaeus 15 (1986) passim, and on the pieces of the Seuso-treasure (quadruped, mugs, buckets), NAgY, M. -TóTH, E.: The Seuso Treasure. The Pannonian Connection? Minerva 1.7 (1990) 4-11, here 9.

${ }^{37}$ It is common on coin depictions. The earliest mount of Constantinople dates from 330 (RIC IX 18. board 44), where the Emperor sitting on the throne is sided by two Caesars. Similar depictions can be seen on the mounts of Constantius II and Valentinianus and Valens, who are often sitting next to each other. See the trial of Christ in the Rossano Gospel, 6th century, Brown, P.: The World of Late Antiquity. From Marcus Aurelius to Mohammed. London 1971, 43, fig. 32.

${ }^{38}$ EngEMANN, J.: Die imperialen Grundlagen der frühchristlichen Kunst. In Spätantike und frühes Christentum. Ausstellung im Liebieghaus, Museum Alter Plastik, Frankfurt am Main, 16. Dezember 1983 bis 11. März 1984. Frankfurt am Main 1983, 260-266, here 261. the Lord.

${ }^{39}$ The Hebraic word was also used in Greek and Latin in the same form. Its meaning is praising ${ }^{40}$ RIC VII Constantinus, nr. 44, T. 18.
} 


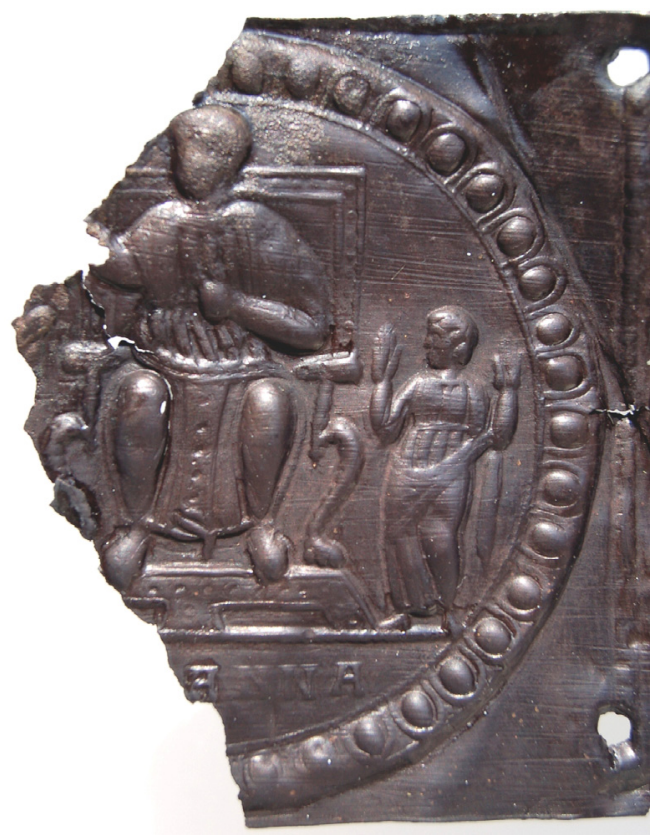

6. Obverse of the left-hand scene [Hos] anna of the bronze plate with biblical scenes. (C) Zs. Visy

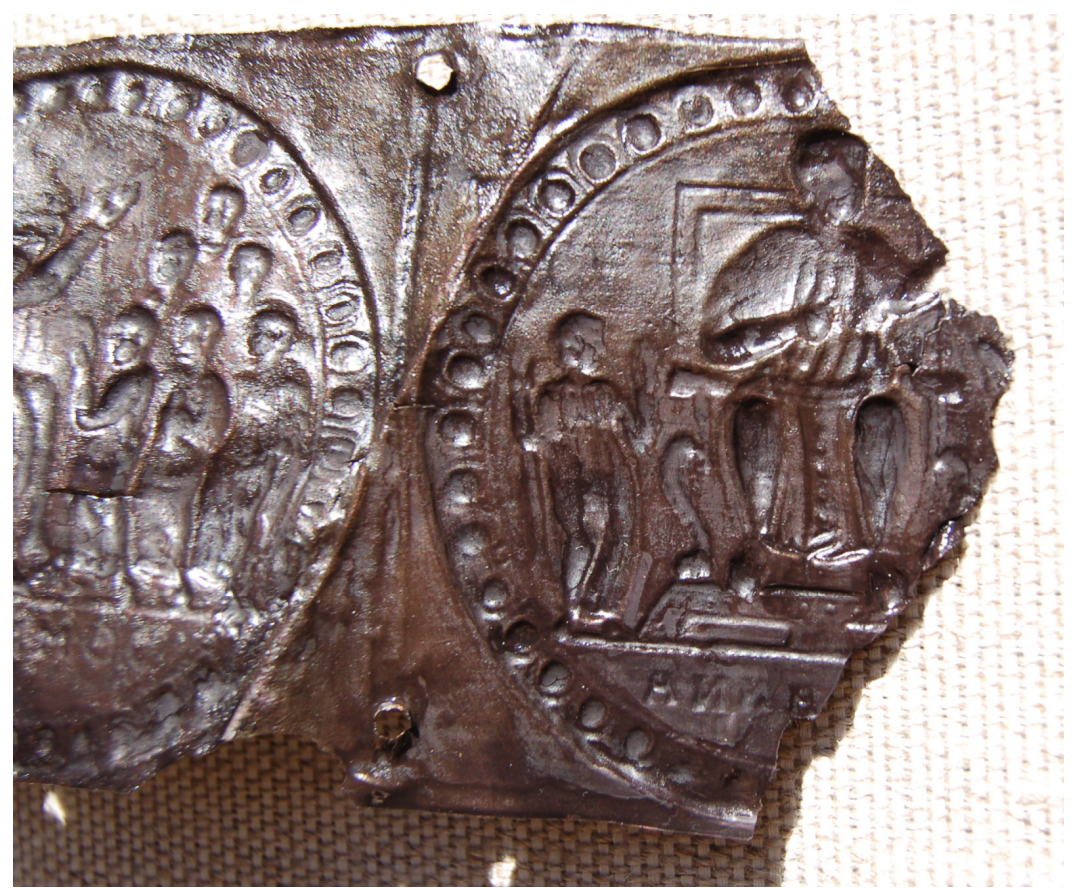

7. Reverse of left-hand scene [Hos]anna of the bronze plate with biblical scenes. @ Zs. Visy 
minted in 330 , but it was used later on as well. ${ }^{41}$ The depiction seen on the mount and found in Bakonya is closely related to them, but the casket mounts of Vermand, ${ }^{42}$ Neuss $^{43}$ and Isauria, ${ }^{44}$ one of the wall paintings of SS. Marcellino and Pietro from Rome $^{45}$ can also be mentioned among the analogies of the late 4th century.

In the middle picture another Dominus depiction can be seen fully intact (figs 8-9). The Lord is sitting on a lion-legged imperial throne with a dotted twin-framed back standing in the right part of the depiction. A horizontal rib represents the bottom of the scene. The Dominus, wearing a toga and a pallium and shown from a semi-profile front view, is holding the scrolls of laws in his left, while his right hand is giving blessings. The smaller followers are standing just in front of the Dominus. Three figures are in the foreground, while two more persons are above them and one more head is at the top. All of them are wearing long dresses and are facing the Dominus. They are standing, with knees slightly bent. The first figure may be holding a piece of bread in his right hand, while the other one behind him is holding a round object. The close analogy of the picture appears on a casket mount from Császár, which is decorated by a Christogram as well. ${ }^{46}$ The interpretation of the scene is probably maiestas Domini, ${ }^{47}$ which is somewhat supported by the inscription from Bakonya: DOMINVS. The depiction of the Sermon on the Mount was also presumed for this type of decoration. ${ }^{48}$

The medallion on the right is fully intact, too, and it shows the sacrifice of Isaac (figs 10-11). A horizontal pearled rib represents the bottom of the scene. The stepping Abraham is standing on his left leg, while he is raising the dagger in his right hand. He is facing to the right and grabbing Isaac's head with his left hand. Next to him is the naked Isaac, kneeling on his right knee. His hands are bound behind his back. The sacrificial altar with the blazing fire is on the right side of the scene. Above the flames the Lord's hand can be seen. On the other side of Abraham there is a bush with a ram facing Abraham. On the bottom part of the medallion the inscription ABRAHAN can be read. Two pieces of such a picture were also found in the

${ }^{41}$ Constantius II, RIC VIII, nr. 404, 12. board, and on the common coins of Valentinianus and Valens, cf. RIC IX passim, and the medallion depicting the two emperors.

${ }^{42}$ BuSCHHAUSEN, H.: Die spätrömischen Metallscrinia und frühchristlichen Reliquiare. Wiener Byzantinische Studien 9 (1971) 137, A 66, Taf. 83-84, only a drawing, because the item was lost.

${ }^{43}$ Buschinausen (n. 42) 208-209, B 6, Taf. 20. - The glass casket found in the sarcophagus was lost. There is only a picture of it.

${ }^{44}$ BuschHaUSEN (n. 42) 191, B 4, Taf. 13. - This finding, which can be dated to the 5th century, was registered by the non-existent Cirga site. Since it was found in a robbery excavation, the exact site cannot be located accurately.

${ }^{45}$ DECKERS, J.: Constantin und Christus. In Spätantike und frühes Christentum (n. 38) 267-283, here 274, fig. 113.

${ }^{46}$ BuschHAusen (n. 42) 142, A 69, Taf. 87; GÁSPÁR: Römische Kästchen (n. 36) 145-146, kat. 349, Taf. 48,1.

${ }^{47}$ GÁSPÁR: Römische Kästchen (n. 36) 146, with the interpretation of the imperial casket mount.

${ }^{48}$ SUPKA, G.: Frühchristliche Kästchenbeschläge aus Ungarn. Römische Quartalschrift 27 (1913) 162-191, here 168-170. 


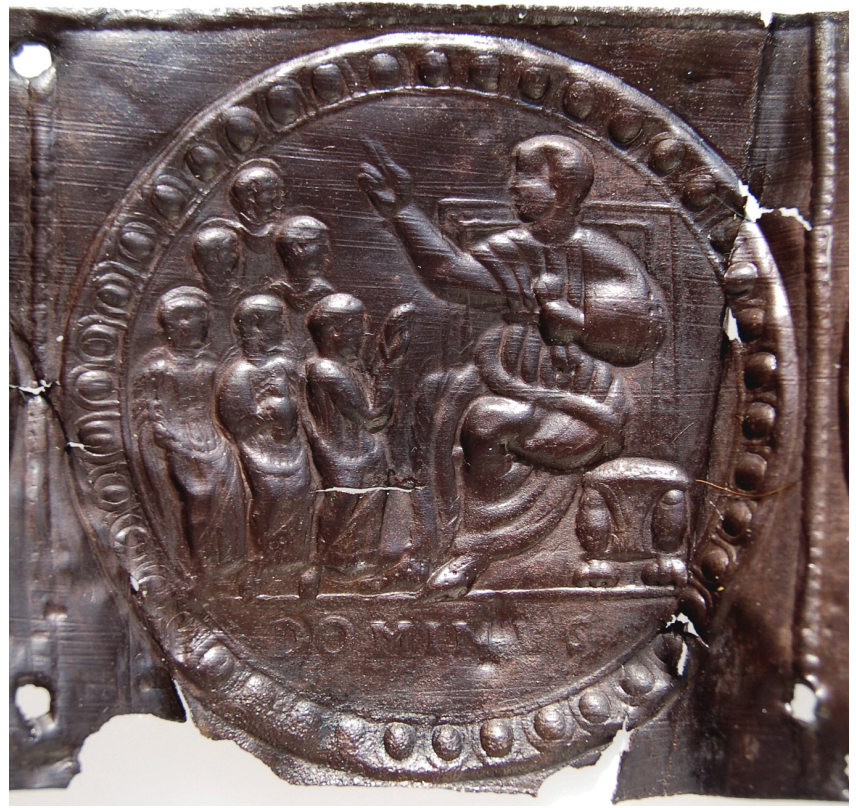

8. Obverse of the middle scene Dominus of the bronze plate with biblical scenes. (C) Zs. Visy

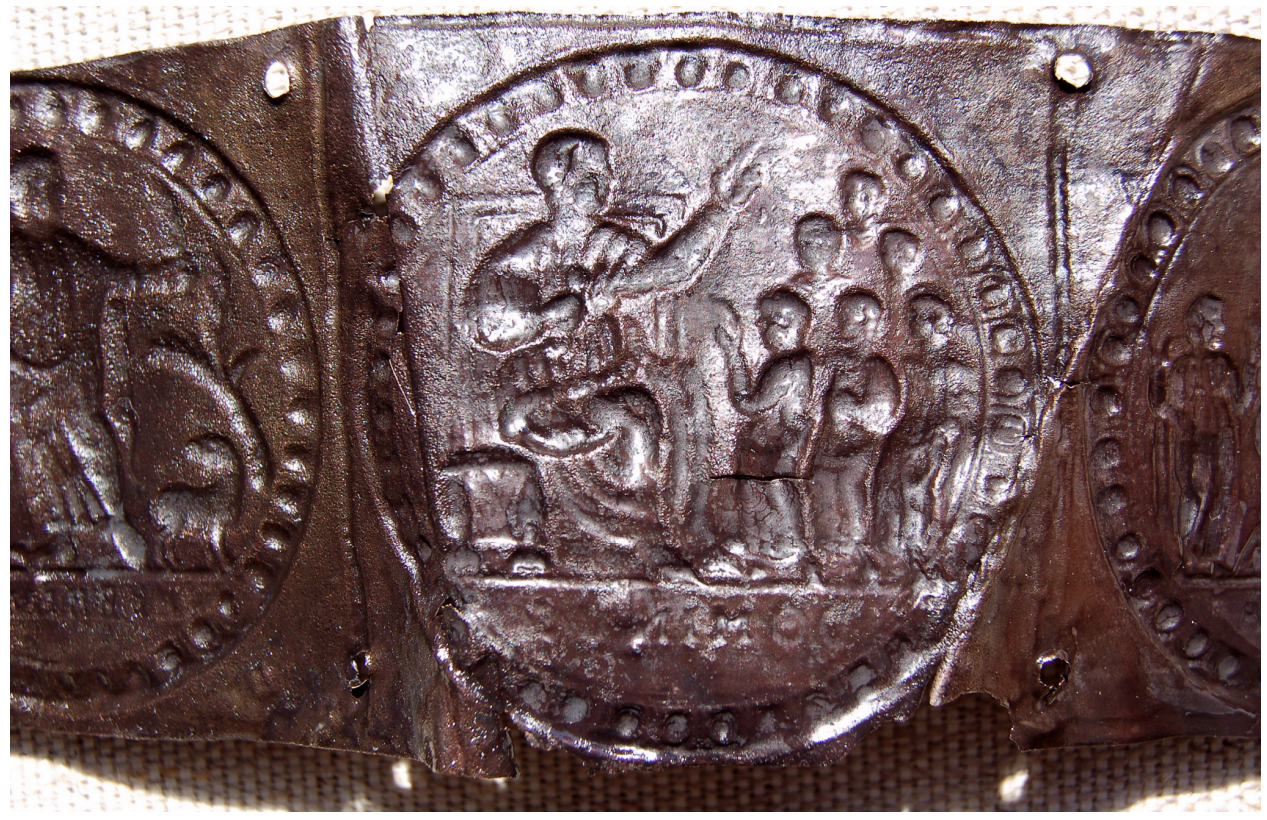

9. Reverse of the middle scene Dominus of the bronze plate with biblical scenes. @ Zs. Visy 


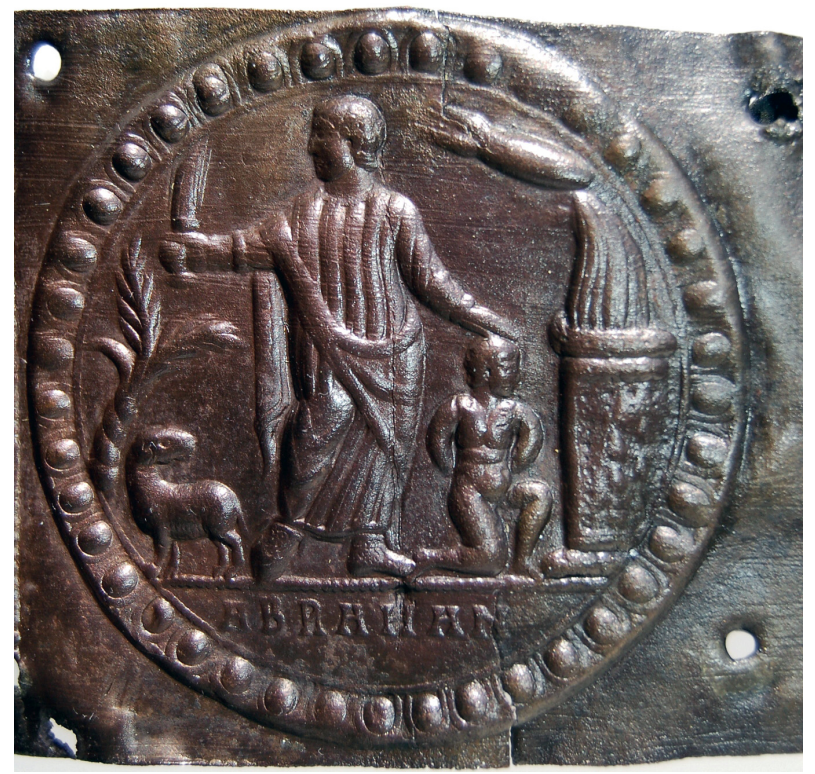

10. Obverse of the right-hand scene Abrahan of the bronze plate with biblical scenes. @ Zs. Visy

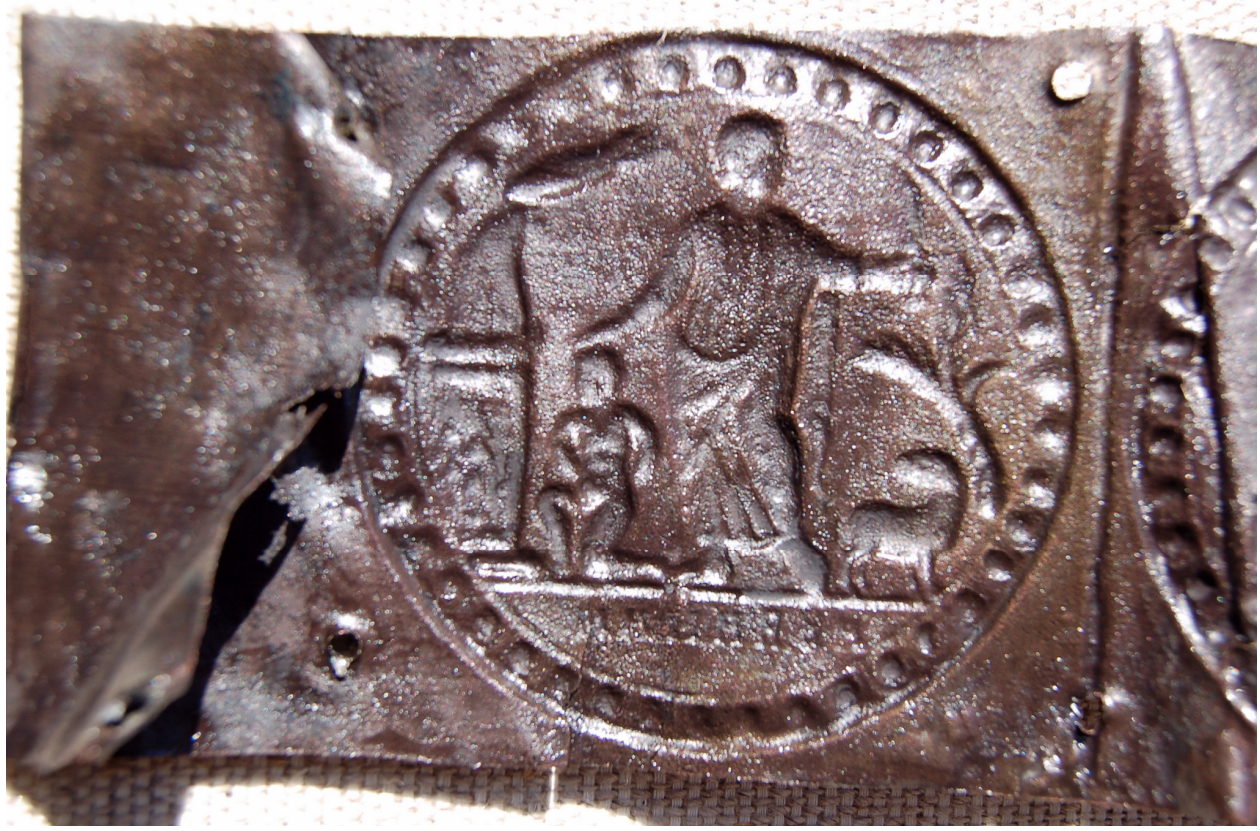

11. Reverse of the right-hand scene Abrahan of the bronze plate with biblical scenes. @ Zs. Visy 
Rhineland, ${ }^{49}$ and it can be seen on the casket from Császár as well ${ }^{50}$ The known depictions were made on different dies.

On the casket mount all figures are wearing a long tunic covering their whole body to the ankles, with multiple reeds in the front, as well as a pallium over their shoulders. The inscriptions below the scenes are a rare peculiarity of the mount from Bakonya.

The other bronze casket mount was found in a folded position as well. After having been cautiously opened the upper left part of a personified representation of Winter could be revealed. The plate is rather thin, with several cracks. Several small pieces were found around the plate. They could be fitted to the main body of the plate during the restoration. It measures $11.9 \times 11.5 \mathrm{~cm}$ and is $0.2 \mathrm{~cm}$ thick (figs 12-13). The bronze plate was nailed to the wooden casket. Three holes are visible: one in the upper left corner, the second $5.1 \mathrm{~cm}$ to the right, also in the upper edge. The third one is to be seen between the animal frieze and the main composition. The nails were placed so as not to disturb the decoration. All the scenes were made with the pressing method. In the upper and left parts of the main scene, lion and bull friezes can be observed. They are running to the left amongst bushes. The friezes are framed with partly dotted ribs. The three animals above are lions on both sides, with maybe a bull in the middle. On the left side a part of the same frieze can be seen but only with two animals, a lion and a bull. The other two sides of the plate are broken. Animal friezes were often used on casket mounts. The closest analogy of the aforementioned item can be seen on a casket from Intercisa. ${ }^{51}$

The central scene has been framed by a pearled stripe with thin ribs on both sides. In the middle of the rectangular frame the upper part of a man can be seen. He was represented in a frontal position, facing left. His face is deformed because the line of the folding went through it. He is wearing a long, pleated tunic. On the shoulders a fur cloak can be seen, its grooved corners are blown by the wind like wings. He is holding a hare by its hind feet in his right hand, and a stock in his left as in Fenékpuszta, ${ }^{52}$ but this part of the scene was almost fully broken. Another possibility is that one or two ducks hung from it as in a plate from Intercisa. ${ }^{53}$ The decoration represents Winter. The pressed mount depicted the four seasons, but only a part of Winter survived. A further analogy can be mentioned from Gorsium. ${ }^{54}$

The closest analogy of the mount of Bakonya with biblical scenes is the mount of the casket from Csákvár. There are four biblical scenes on it framed by a simple

${ }^{49}$ BuschHAusEN (n. 42) 136-138, A 66, Taf. 83-84 - Vermand, the item was lost, and 109-110, A 54, Taf. 61-65.

${ }^{50}$ GÁSPÁR: Römische Kästchen (n. 36) kat. 349, Taf. 48-49.

${ }^{51}$ BuschHAusen (n. 42) A 93, Taf. 98 = GÁsPÁR: Römische Kästchen (n. 36) kat. 537, Taf. 28.; very similar friezes can be seen on some other caskets as well, like BUSCHHAUSEN (n. 42) A 26, Taf. 2832 = GÁSPÁR: Römische Kästchen (n. 36) kat. 733, Taf. 10 (Felcsút); BUSCHHAUSEN (n. 42) A 60, Taf. 71 = GÁSPÁR: Römische Kästchen (n. 36) kat. 686 (Intercisa).

${ }_{52}$ MÜLLER, R.: V. századi bronzmüves mühely maradványai Keszthely-Fenékpusztáról. ArchÉrt 105 (1978) 16-17, fig. 5/1 = GÁSPÁR: Römische Kästchen (n. 36) kat. 793, Taf. 16.

${ }^{53}$ BuschHAusen (n. 42) A 46, Taf. 51 = GÁSPÁR: Römische Kästchen (n. 36) kat. 838, Taf. 13.

${ }^{54}$ BuschHAusen (n. 42) A 42, Taf. 47 = GÁsPÁR: Römische Kästchen (n. 36) kat. 1299. 


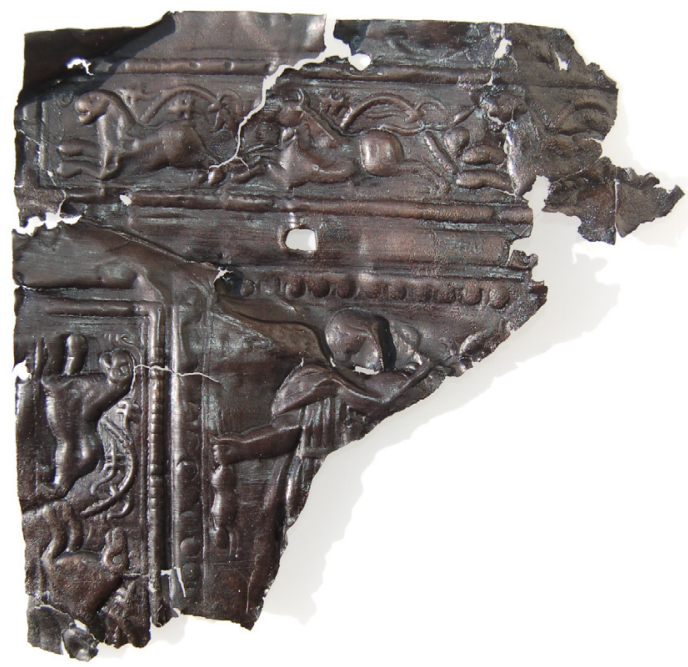

12. Obverse of the bronze plate with the personification of Winter. (C) Zs. Visy

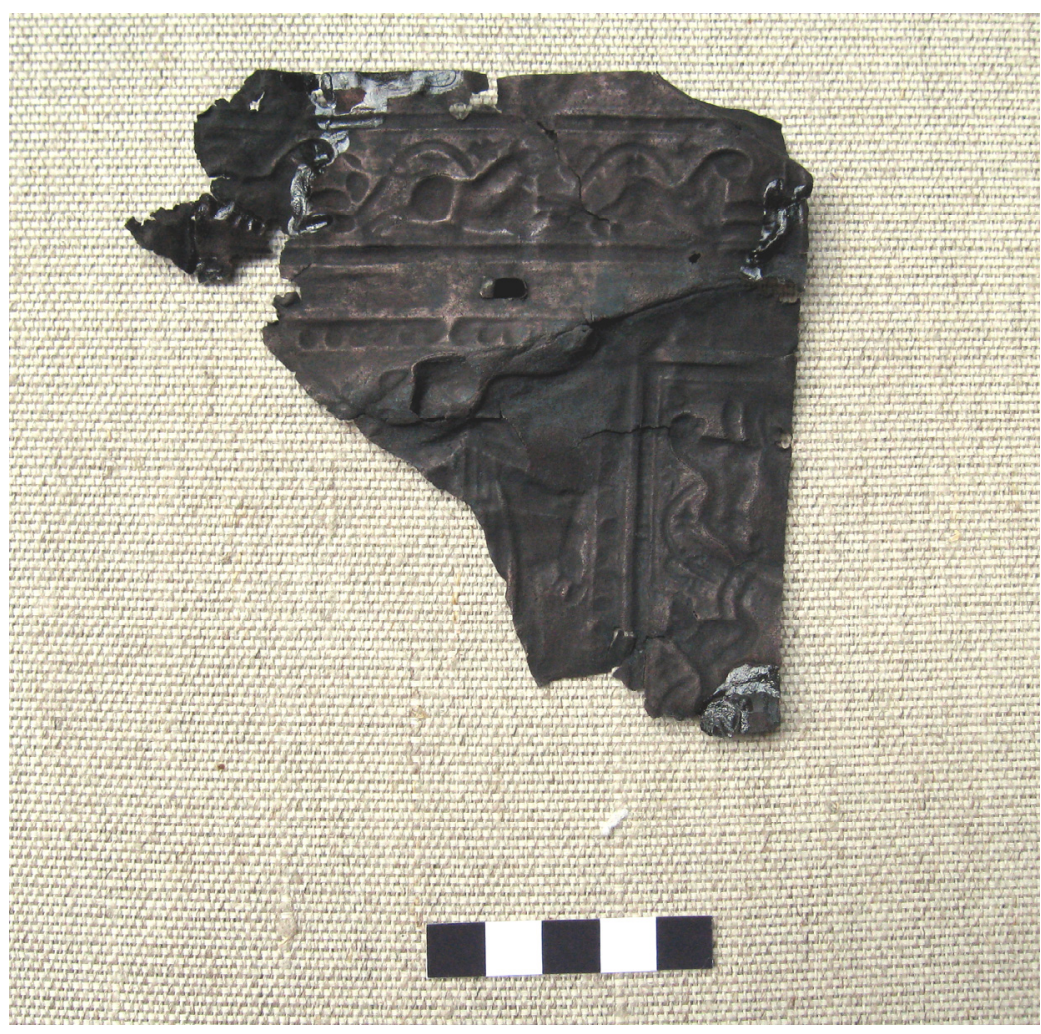

13. Reverse of the bronze plate with the personification of Winter. (C) Zs. Visy 
ring. Two of the scenes are the maiestas Domini and the sacrifice of Isaac, which are also on the plate of Bakonya. The biblical scenes of the two caskets were pressed by different patterns. The pearl-decorated ring is not so common, but it is generally used on the rectangular frames of the four seasons and other profane depictions. The picture of Winter found in Bakonya also has the same decoration. Despite the incompleteness of the mount of Bakonya, the animal frieze of the mount from Intercisa not only seems to be similar, but it may have been made by the same presser. The casket from Intercisa also proves the existence of both Christian and pagan scenes on the same caskets.

Although the mounts decorated with early Christian scenes and with the personification of Winter were found in the same site, it is unlikely that they were fixed on the same casket. Not only because their contents and sizes differ from each other, but also due to their thickness and quality. However, the originally unrelated mounts could have been fixed later on the same casket as well.

The origin of the mounts can be determined only within a wide time span. Due to the type with the Emperor sitting on the throne, it could not have been made before the thirties of the 4th century, but it is unlikely that they were produced after the death of Valentinianus. The most likely date of their production is the middle decades of the 4th century or during the rule of Valentinianus. The fact that they were found in a rich villa built next to Sopianae indicates that they were owned by a wealthy, maybe Christian person living in Sopianae.

\author{
Prof. Zsolt Visy \\ Department of Archaeology \\ University of Pécs \\ Hungary
}

Open Access. This is an open-access article distributed under the terms of the Creative Commons Attribution 4.0 International License (https://creativecommons.org/licenses/by/4.0), which permits unrestricted use, distribution, and reproduction in any medium, provided the original author and source are credited, a link to the CC License is provided, and changes - if any - are indicated. (SID_1) 